\title{
ANALYSIS OF LONG-TERM DATA ON URANIUM IN AIR
}

Merwyn Sanders

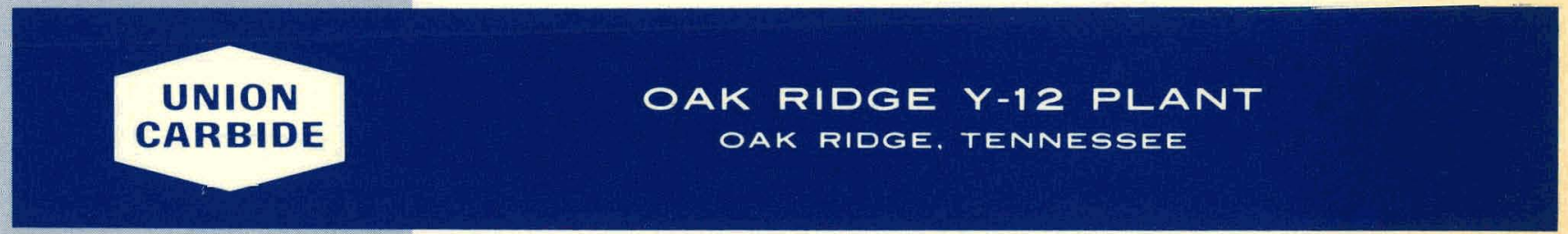

prepared for the U.S. ENERGY RESEARCH AND DEVELOPMENT ADMINISTRATION under U.S. GOVERNMENT Contract W-7405 eng 26

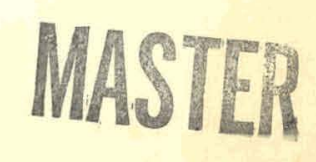




\section{DISCLAIMER}

This report was prepared as an account of work sponsored by an agency of the United States Government. Neither the United States Government nor any agency Thereof, nor any of their employees, makes any warranty, express or implied, or assumes any legal liability or responsibility for the accuracy, completeness, or usefulness of any information, apparatus, product, or process disclosed, or represents that its use would not infringe privately owned rights. Reference herein to any specific commercial product, process, or service by trade name, trademark, manufacturer, or otherwise does not necessarily constitute or imply its endorsement, recommendation, or favoring by the United States Government or any agency thereof. The views and opinions of authors expressed herein do not necessarily state or reflect those of the United States Government or any agency thereof. 


\section{DISCLAIMER}

Portions of this document may be illegible in electronic image products. Images are produced from the best available original document. 
Reference to a company or product name does not imply approval or recommendation of the product by Union Carbide Corporation or the U.S. Energy Research and Development Administration to the exclusion of others that may meet specifications.

Printed in the United States of America. Available from National Technical Information Service

U.S. Department of Commerce

5285 Port Royal Road, Springfield, Virginia 22161

Price: Printed Copy $\$ 4.00$; Microfiche $\$ 2.25$

This report was prepared as an account of work sponsored by the United States Government. Neither the United States nor the Energy Research and Development Administration, nor any of their employees, nor any of their contractors, subcontractors, or their employees, makes any warranty, express or implied, or assumes any legal liability or responsibility for the accuracy, completeness or usefulıess of any information, apparatus, produrt or prncess disclosed, or represents that its use would not infringe privately owned rights. 
Date of Issue: September 29, 1975

Report Number: Y-1992

Distribution Category: UC-41

\title{
ANALYSIS OF LONG-TERM DATA ON URANIUM IN AIR
}

\author{
Merwyn Sanders \\ Health Physics Department \\ Y-12 Technical Division
}

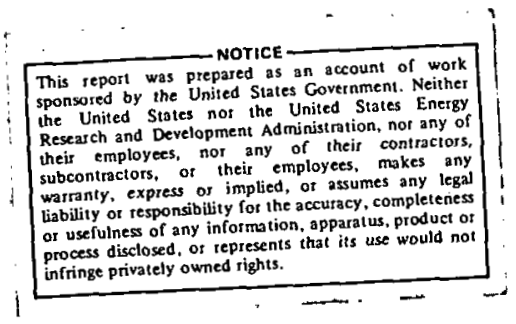

Oak Ridge Y-12 Plant

P. O. Box Y, Oak Ridge. Tennessee 37830

Prepared for the US Energy Resparch and Development Administration

Under US Government Contract W-7405-eng-26 


\begin{abstract}
The Oak Ridge Y-12 Plant, primarily a manufacturing facility geared to the fabrication and processing of uranium into components to fulfill the nuclear weapon defense needs of the United States, maintains positive engineering control to reduce uranium airborne activity to a safe and acceptable level in the working environment.
\end{abstract}


CONTENTS

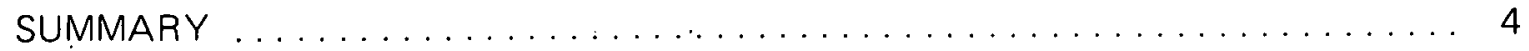

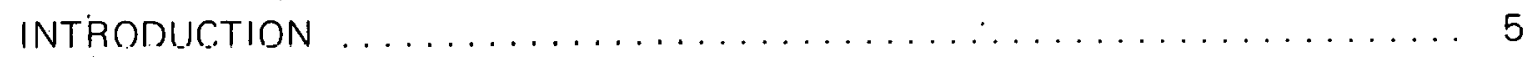

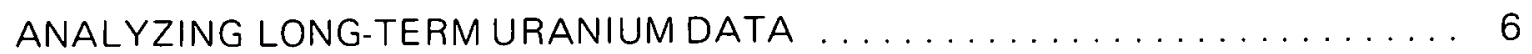

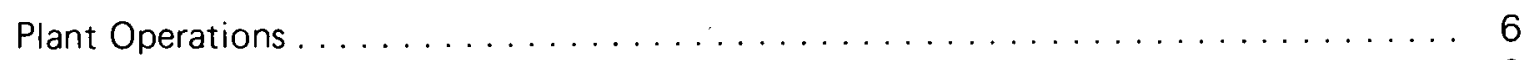

Enriched Uranium Processes . . . . . . . . . . . . . . . . . . . . 6

Depleted Uranium Processes . . . . . . . . . . . . . . . . . . . . 10

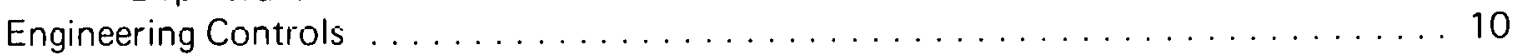

Radioactive Effluent from Exhaust Stacks . . . . . . . . . . . . . . 10

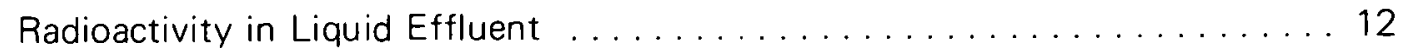

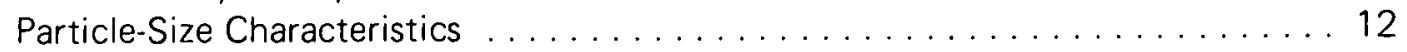

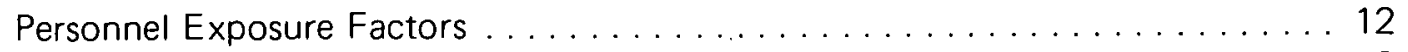

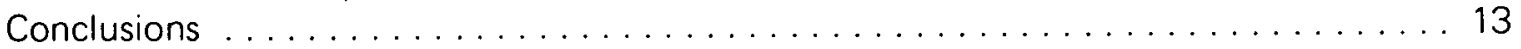




\section{SUMMARY}

Plant operations at $\mathrm{Y}-12$ are under positive engineering control to reduce uranium airborne activity to acceptable levels. This control is maintained through: (1) monitoring the radioactive effluents from exhaust stacks, (2) determining the level of radioactivity in liquid effluents, (3) studying particle-size characteristics, and (4) controlling those factors that pertain to personnel exposure. 


\section{INTRODUCTION}

The main function of the Oak Ridge $\mathrm{Y}-12$ Plant's(a) uranium processing areas is to convert raw materials to rough shapes suitable for machining and finishing to an exact configuration. The Plant also recycles waste materials generated by the various manufacturing processes. The processes which have been selected for discussion are those where long-term experience has demonstrated that positive engineering techniques are required for effective control of uranium airborne activity in the working environment and in the outside environs. These operations are (as they pertain to those areas where enriched uranium is processed): (1) reduction of UF4 to metal, (2) casting, (3) rolling and forming, (4) machining, (5) wet chemistry recycle, and (6) UF 4 extraction. In the work with depleted uranium, the rolling and forming and foundry operations are of primary concern.

(a) Operated by the Union Carbide Corporation's Nuclear Division tor the US Energy Research and Development Administration. 


\section{ANALYZING LONG-TERM URANIUM DATA}

\section{PLANT OPERATIONS}

\section{Enriched Uranium Processes}

Reduction of $\mathrm{UF}_{4}$ to Metal - Keduction of UF4 to uranium metal is performed in the facility shown in Figure 1. This facility consists of a variety of ventilated enclosures that range in type from absolute-filtered, inlet glove boxes to open-face hoods with a minimum face velocity of 120 linear feet per minute. The general-air and permanent-operational air samplers for this process for the last seven years revealed results well below the recommended levels for occupational exposure, as given in Figure 2.

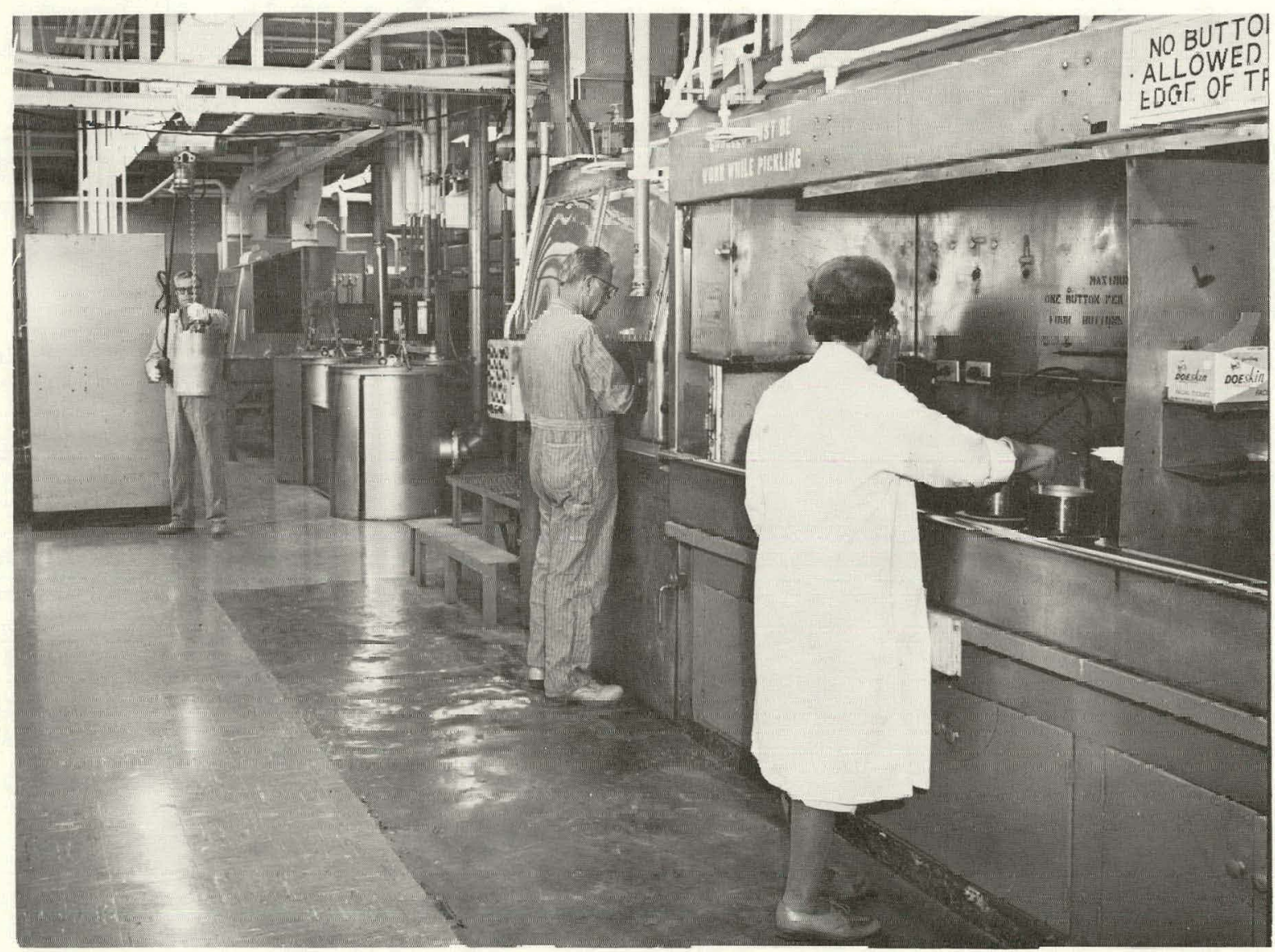

Figure 1. ENRICHED URANIUM REDUCTION FACILITY.

147367

Casting - The uranium casting facility is well designed, self contained, and under a negative pressure of 0.5 inch of water in relation to the working environment. The working environment is also under negative pressure in relation to the surrounding process areas, thus providing double containment for the casting area. All casting operations are performed by remote control. The general-air and permanent-operational air sampler results reveal acceptable levels for the past seven years, as reported in Figure 3. 


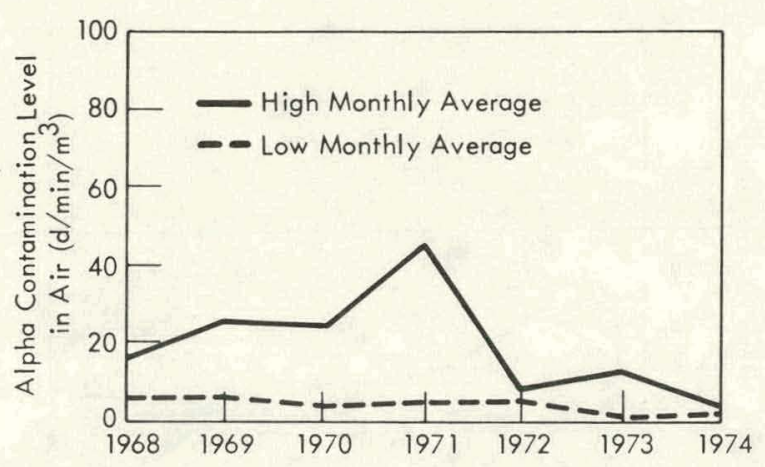

Figure 2. TRENDS IN THE LEVELS OF AIR CONTAMINATION DURING REDUCTION OF URANIUM TETRAFLUORIDE TO URANIUM METAL. (Enriched Uranium)

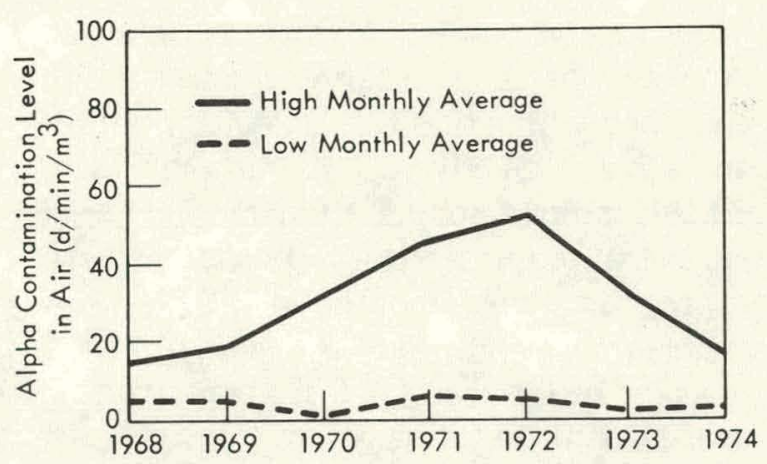

Figure 3. TRENDS IN THE LEVELS OF AIR CONTAMINATION DURING URANIUM CASTING OPERATIONS. (Enriched Uranium)

Rolling and Forming - The rolling and forming area, seen in Figure 4, is much like the casting area from a ventilation standpoint. All operations are performed by remote control. Air-sample data from these operations reveal excellent control, as given in Figure 5.

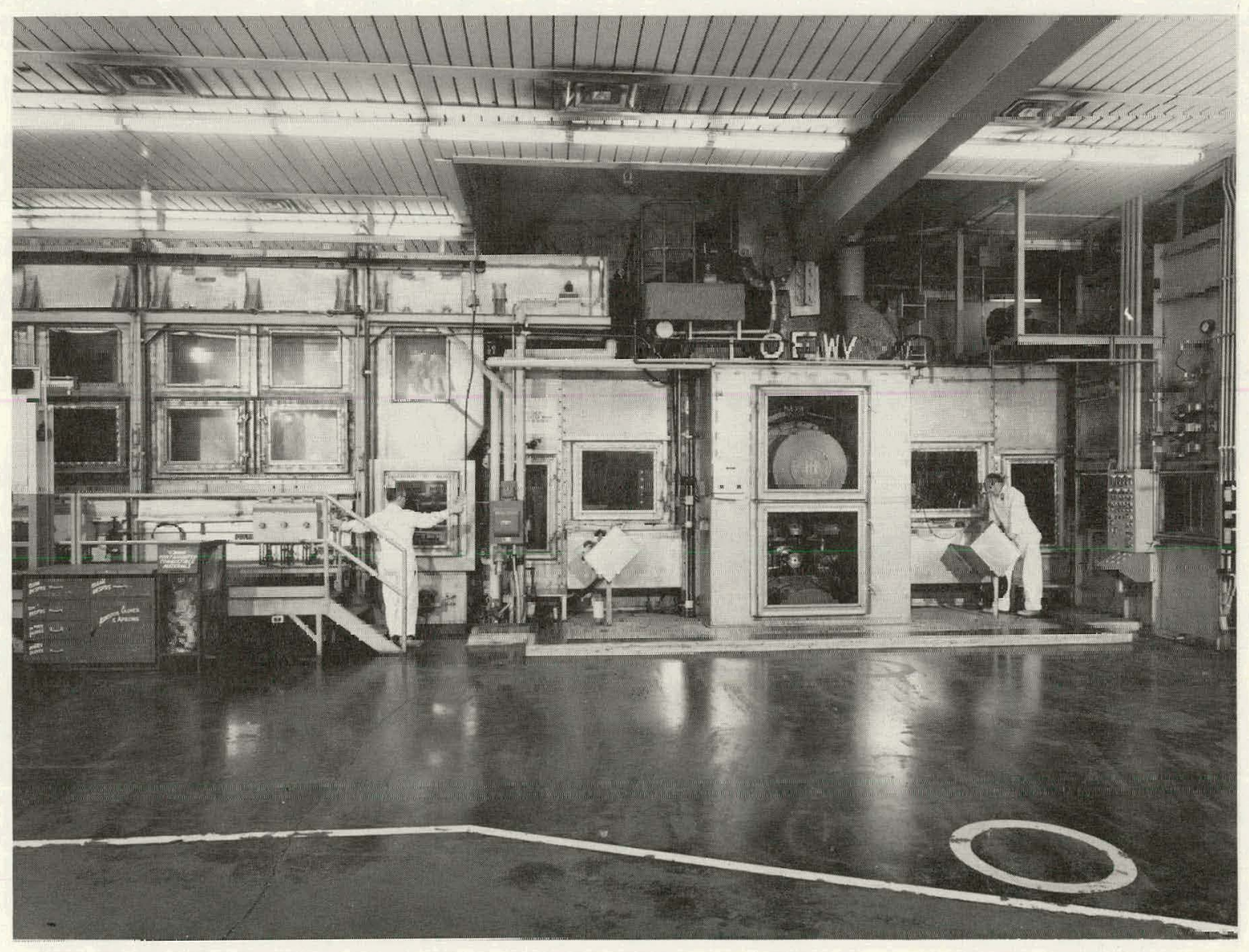

109415

Figure 4. ENRICHED URANIUM ROLLING AND FORMING FACILITY.

Machining - Machining of enriched uranium requires that the operation be performed wet, with a suitable machine coolant (low hydrogen content) and partial hood enclosure with a 
linear face velocity of 150 feet per minute. A view of a typical machine setup, equipped with a hood and exhaust prefilter and a demister unit, is presented in Figure 6. Air-sample results (Figure 7) reveal excellent control of airborne activity except for one month in 1971. This problem was caused by a fire in the machine-tool exhaust air system, resulting in the automatic shut down of the exhaust air. Because the shut down was automatic, there was no release to the atmosphere.

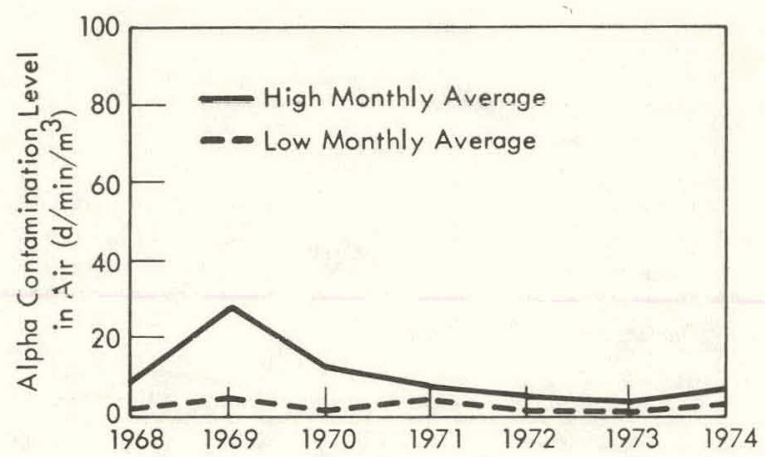

Figure 5. TRENDS IN THE LEVELS OF AIR CONTAMINATION DURING ROLLING AND FORMING OPERATIONIS. (Fnriched I Iraniım)

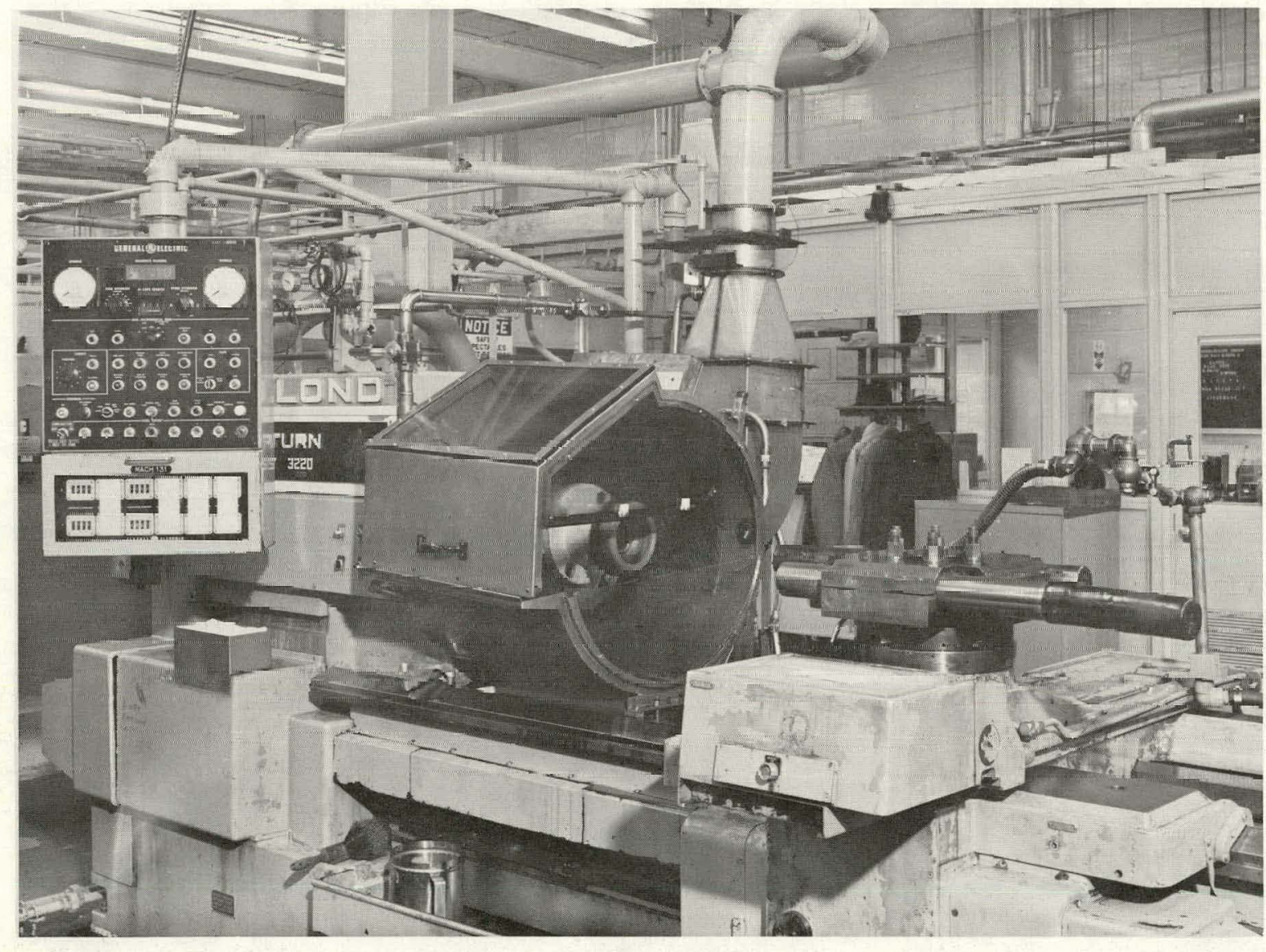

Figure 6. ENRICHED URANIUM MACHINING FACILITY.

159756

Wet-Chemistry Recycle Not all enriched uranium requires chemical processing. Very pure unalloyed uranium may be broken up and recast. Chips from the machine shop are briquetted and also recast. Alloys and less-pure uranium metal and oxides are dissolved and may then enter the chemical stream according to their concentration and purity. 


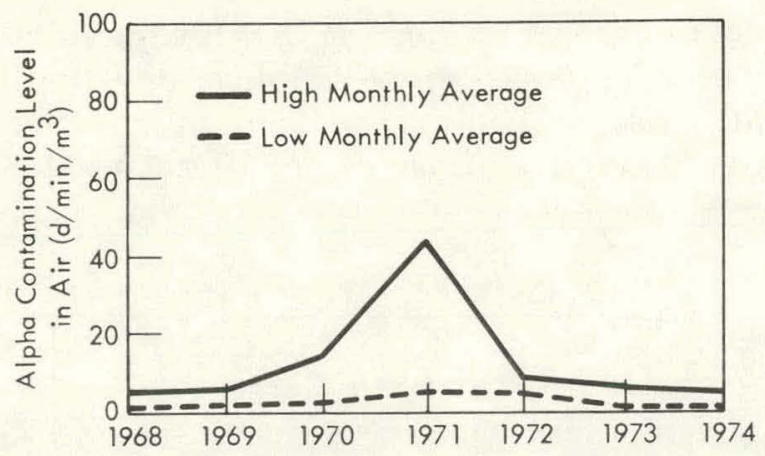

Figure 7. TRENDS IN THE LEVELS OF AIR CONTAMINATION DURING URANIUM MACHINING. (Enriched Uranium)
Combustibles, such as impure metal chips, mops, cloth and paper wipes, and carbon molds, are incinerated. These materials are burned in special burners that have absolute exhaust filters that discharge to a monitored stack. The ash from the burners is leached with nitric acid to recover the uranium in a process which looks like a "plumber's nightmare" (Figure 8). Since 1968, many improvements have been made to improve the control of airborne activity in the uranium recovery and recycle processess (Figure 9). Accomplishment of this objective can be attributed to process improvement, ventilation changes, improved procedures, and training of personnel.

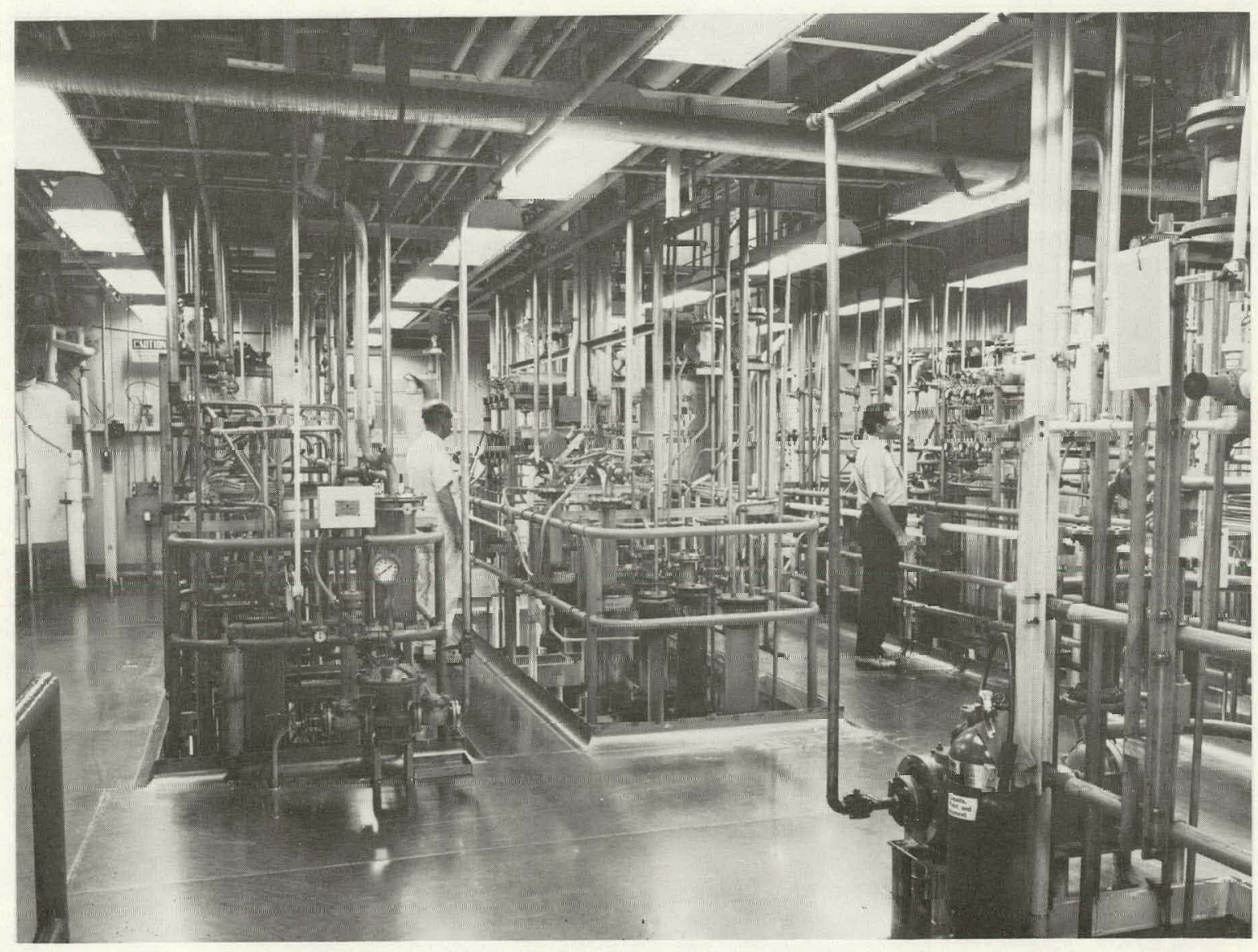

Figure 8. WET-CHEMISTRY RECYCLE RECOVERY AREA

147368

UF $_{4}$ Extraction - Pure uranyl nitrate produced in the recycle area is denitrated to uranium trioxide $\left(\mathrm{UO}_{3}\right)$ by heating. The resulting fumes are scrubbed in nitric acid to recover the 
uranium and to decrease the output of the oxides of nitrogen $\left(\mathrm{NO}_{x}\right)$. The $\mathrm{UO}_{3}$ is reduced to uranium dioxide $\left(\mathrm{UO}_{2}\right)$ with hydrogen and then is converted to the tetrafluoride $\left(\mathrm{UF}_{4}\right)$. The $U_{4}$ is removed through a well-designed glove box line that contains an interlock system that permits container cleaning and bagging before removal. Figure 10 summarizes the uranium airborne data from the UF 4 production facility.

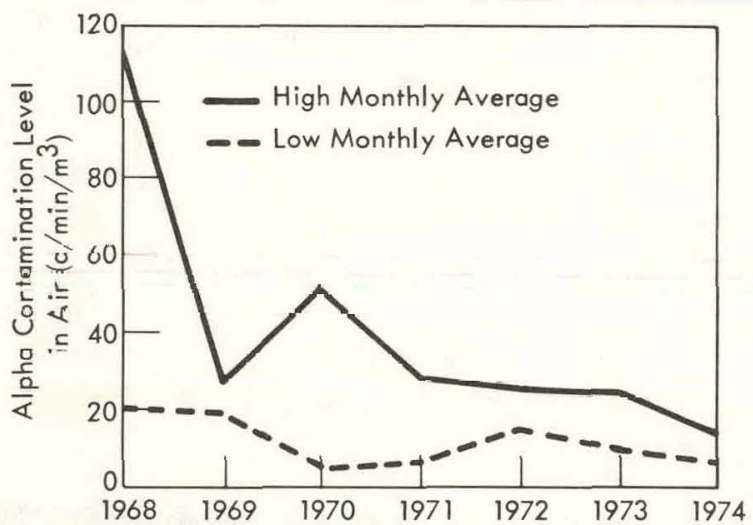

Figure 9. TRENDS IN THE LEVELS OF AIR CONTAMINATION DURING WET-CHEMISTRY RECYCLE OP. ERATIONS. (Enriched Uranium)

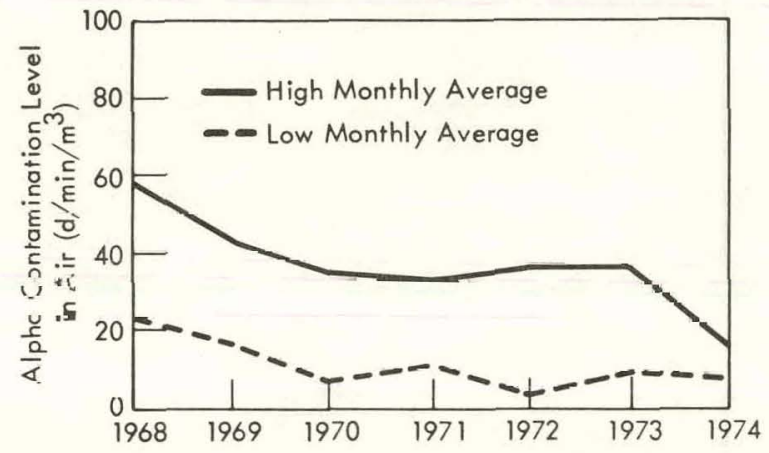

Figure 10. TRENDS IN THE LEVELS OF AIR CONTAMINATION DURING THE EXTRACTION PROCESS IUF 4 Production)

\section{Depleted Uranium Processes}

Rolling and Forming - Rolling and forming of depleted uranium requires some degree of control from a health standpoint. As seen in Figure 11, the rolling mill is equipped vvill up-draft and down-draft ventilation, since the operation is performed dry without the benefit of a coolant. The data, as given in Figure 12, reveal levels of uranium airborne activity well below an acceplable level in the working environment. Forming operations, as noted in Figure 13, require local ventilation around the $\mu$ ess, due, primarily, to the precheat of the metal before and during the operation.

Casting-Casting of depleted uranium is performed in a closed system except for the removal of the cast shape. The knockout of these shapes is performed under positive engineering controls. A very strong vacuum system is used for the removal of the oxide from the casting and carbon trom the molds. This operation is also perfumed on a grid with down-draft ventilation. Results of the effective control of uranium airborne activity from the operation are reported in Figure 14.

\section{ENGINEERING CONTROLS}

\section{Radioactive Effluent from Exhaust Stacks}

The Y-12 Plant has approximately twenty-five million dollars invested in the exhaust clearriny facilities for the process areas. These facilities consist of $95 \%$ efficient and $97.97 \%$ high-efficient particulate absorbers (HEPA), tested to 0.3 micrometer every six months by the DOP technique. All 59 discharge points are sampled continuously by isokinetic samplers in order to detect a malfunction of the system between tests. The total radioactive discharge to the atmosphere for 1974 was 0.085 curie, as measured by these samplers. As noted in 

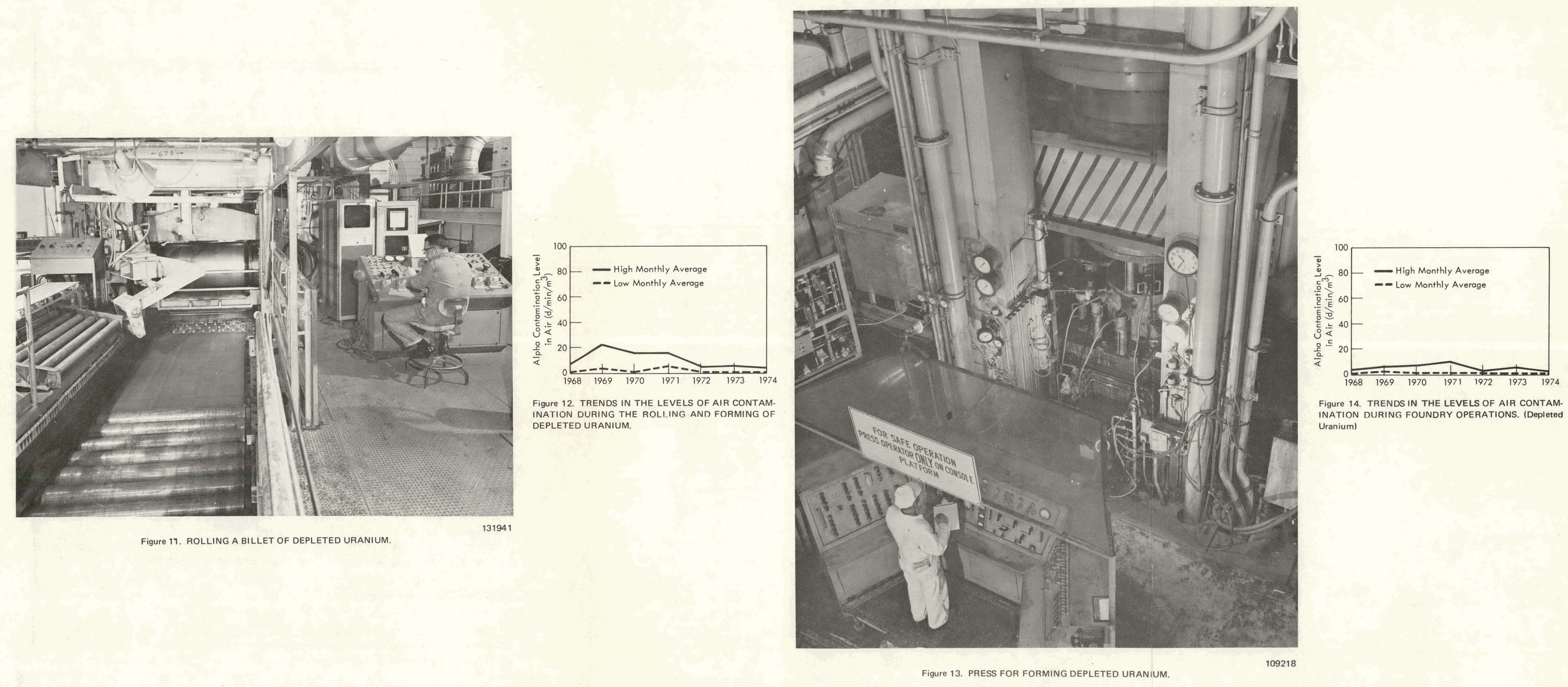
Table 1, the remarkable reduction in the amount of uranium discharged to the atmosphere can be attributed to a one-million-dollar upgrading of one exhaust cleaning facility in the latter part of 1973.

Table 1

RADIOACTIVE EFFLUENT FROM THE DISCHARGE STACKS

\begin{tabular}{cccccccc}
\hline $\begin{array}{c}\text { Tulal Number } \\
\text { of Release } \\
\text { Points }\end{array}$ & 1968 & 1969 & 1970 & 1971 & 1972 & 1973 & 1974 \\
\cline { 2 - 8 } & 0.35 & 0.35 & 0.40 & 0.33 & 0.36 & 0.36 & $0.085^{(1)}$ \\
\hline
\end{tabular}

(1) Reduction due to improvements and modification of the exhaust system.

\section{Radioartivity in I ıquın rttlıent}

Once-thrnugh prosess rnnling water, blow down from the cooling towors, and outflow from the storm sewers are discharged via New Hope Pond into the East Fork of Poplar Creek. New Hope Pond, which is a mixing and settling basin, is a man-built retention pond consisting of 29 water acres. The inlet and outlet of the pond are sampled by proportional samplers which provide samples for radioactive analyses. The uranium alpha activity analysis from these samples, as given in Figure 15, reveals results well below the recommended levels of the International Commission on Radiological Protection (ICRP).

\section{Particle-Size Clıaracteristics}

Samples collected by a modified cascade impactor were collected at various operations in the uranium proccssing arcas (summarized

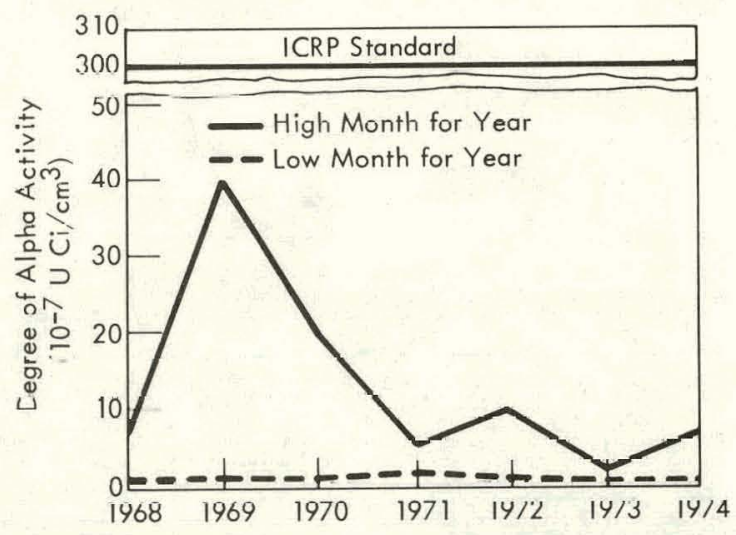

Figure 15. TRENDS IN THE LEVELS OF URANIUM ALPHA CONTAMINATION IN THE LIQUID EFFLU. ENT FROM THE Y-12 PLANT.

in Table 2). Each stage of the impactur was counted for gross alpha activity. Particle-size determinations were made with an electron microscope. These results reveal that foundry operations (vvlich pruduce uranium oxides) produce the highest percentage of arrborne particles in the lower lung-inhalation range, while the wet machining and reduction operations (U厂 4 to metal) have (lie sirlallest percent of particles. Therefore, the degree of pesitive engineering control required can be diclated by a particle sižc analysis.

\section{Personnel Exposure Factors}

The real proof of how effective a program is in controlling the level of uranium alpha airborne activity in the working environment is best determined by an evaluation of an employee's internal exposure. Table 3 gives a summary of $Y-12$ 's experience for the past seven years through in vivo and urinalysis measurements. Metal preparation, which includes such operations as recycle, reduction, and casting, reveals, as might be anticipated, the area 
where sound engineering controls are a necessity. In machining and support groups, the degree of containment is much easier to implement.

Table 2

SIZES OF AIRBORNE URANIUM PARTICLES IN THE PROCESS AREAS

$\left.\begin{array}{lccc}\hline \multicolumn{1}{c}{\text { Operation(1) }} & \begin{array}{c}\text { Mass Median } \\ \text { Diameter (2) } \\ (\mu \mathrm{m})\end{array} & \begin{array}{c}\text { Standard } \\ \text { Deviation }\end{array} & \begin{array}{c}\text { Percent Activity from } \\ <7 \mu \text { Particles }\end{array} \\ \hline \text { Foundry } & 2.8 & 2.7 \\ \quad \text { Depleted Uranium } & 3.3 & 2.2 \\ \quad \text { Enriched Uranium (Sample 1) } & 2.1 & 2.0\end{array}\right)$

(1) Samples taken with a cascade impactor.

(2) Particle-size determination by electron microscope.

Table 3

URANIUM INTERNAL MONITORING

\begin{tabular}{|c|c|c|c|c|c|c|c|c|}
\hline \multirow[b]{2}{*}{ Process } & \multirow{2}{*}{$\begin{array}{c}\text { Number of Employees } \\
\text { in the Monitoring } \\
\text { Program }\end{array}$} & \multicolumn{7}{|c|}{ Percent of ICRP Limit } \\
\hline & & 1968 & 1969 & 1970 & 1971 & 1972 & 1973 & 1974 \\
\hline Metal Preparation & 325 & 18 & 21 & 23 & 22 & 30 & 19 & 18 \\
\hline Machining & 400 & 6 & 5 & 10 & 8 & 10 & 10 & 10 \\
\hline Other & 950 & 6 & 6 & 11 & 10 & 8 & 12 & 10 \\
\hline
\end{tabular}

\section{CONCLUSIONS}

The data presented show that the $\mathrm{Y}-12$ Plant has been very successful in maintaining an effective program for the reduction and control of personnel exposure to uranium airborne activity to the lowest practicable level in the working environment. 


\section{Distribution}

Energy Research and Development Administration - Oak Ridge

Hickman, H. D.

Leed, R. E.

Zachrv, D, S.

National Lead of Ohio

Pennak, A. F.

Oak Ridge Gaseous Diffusion Plant

Șticf, S. S.

Wilcux, W. J., Ji

\section{Oak Ridge National Laboratory}

Witkowski, E. J.

\section{Oak Ridge Y-12 Plant}

Bostock D. J.

Briscoe, O.W.

Burditt, R. B.

Burkhart, L. E.

Dodson, W. H.

Eritt, W. S.

Fraser, H. J.

Gambill, E. F.

Hacusler, K. R.

Hollanid, C. W.

Jones, F.W.

Jordan, R. G.

Keith, A.

Kite, H. T.

Koger, J.W.

Lambdin, $F$.

Lundin, M. I.

Marrow, G. B

McLendon, J. D.

Mills, J. M., Jr

Napier, J. M.
Parsons, J.

Phillips, L. R.

Sanders, M. (5)

Schreyer, J. M.

Smith, H. F., Jr

Smith, R. D.

Stanton, J. A.

Stoner, H. H.

Strohecker, J.W.

Tewes, W. E.

Vavalides, S. P.

Woathorcby, W. E.

Whitson, W. K.

Williarrs, R. D.

Yaggi, W. J./Googin, J. M.

$Y-12$ Central Files (5)

$Y-12$ Central Files (master copy)

$Y-12$ Central Files (route copy)

$Y-12$ Central Files $(Y-12 R C)$

Zerby, C. D.

Paducah Gaseous Diffusion Plant

Baker, R. C.

I evin, R W

In addition, this report is distributed in accordance with the category UC-41, Health and Safety, as given in the USERDA Standard Distribution Lists for Unclassified Scientific and Technical Reports, TID-4500. 